\title{
Moving in mysterious ways: the use and discard of Cambridge college ceramics
}

\author{
Craig Cessford ${ }^{*}$
}

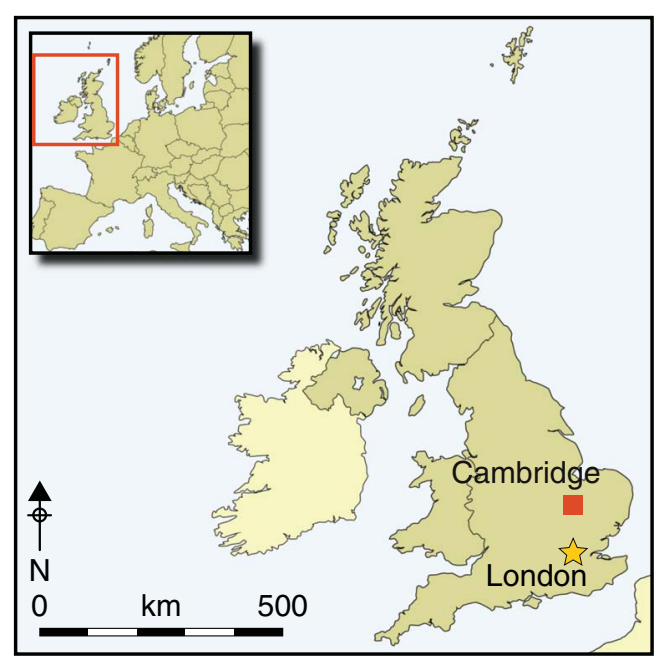

Artefact biographies are a valuable means of conceptualising the relationships between people, places and objects in the past. It is rare, however, that the detailed contextual information required by such approaches can be extracted from the archaeological assemblages typically found in the often dense and confusing palimpsests of complex urban sites. Eighteenth- to twentieth-century ceramic wares associated with Oxbridge colleges provide one way of exploring this issue. Detailed historical records of property owners and tenants can be combined with ceramics linked to individual colleges by corporate markings such as coats of arms or badges. This enables fine-grained reconstructions which show, in many cases, that ordinary vessels had far from ordinary histories of use and discard.

Keywords: UK, Cambridge colleges, post-medieval, ceramics, distribution, artefact biography

\section{Introduction}

When studying portable material culture, archaeologists typically start with depositional context as the only physical location associated with objects that can be determined with a high degree of certainty. One fundamental issue that arises from this situation concerns the relationship between the place of discard and the locations where objects were used and manufactured, with archaeologists effectively working backwards through this sequence. In biographical terms, objects are 'born', go through various stages of 'life' and then 'die' (Kopytoff 1986), which has led to the archaeological concept of the 'object biography' (see Hahn \& Weiss 2013; Joy 2015; Joyce \& Gillespie 2015). Of these three main biographical stages, it is often the 'life' of archaeological objects—arguably the most important stage - about which there is the greatest uncertainty, as archaeologists rarely know where items were used.

* Cambridge Archaeological Unit, Department of Archaeology, University of Cambridge, Downing Street, Cambridge CB2 3DZ, UK (Email: cc250@cam.ac.uk) 

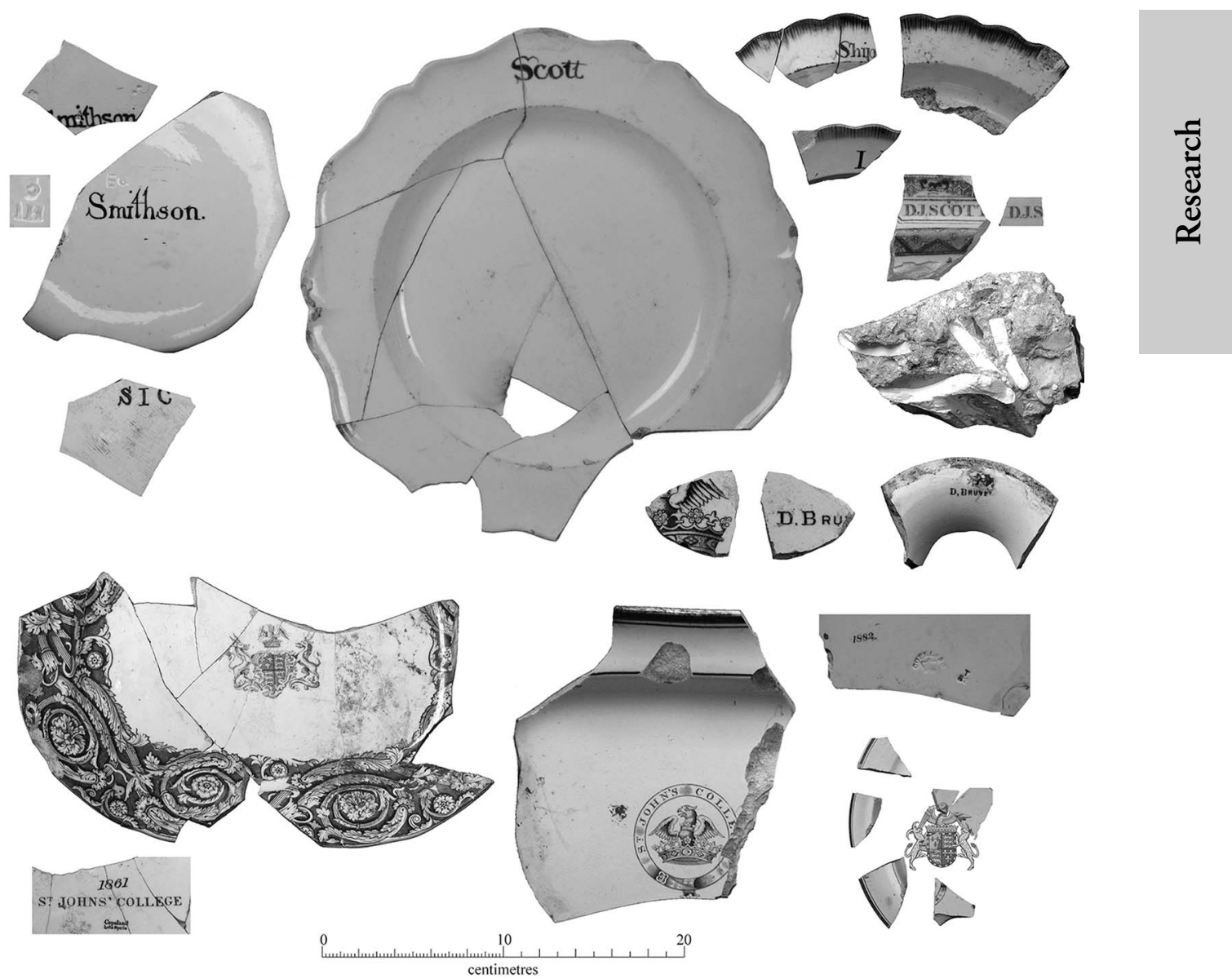

Figure 1. Selection of sherds from late eighteen- to early twentieth-century ceramics produced for use at St John's College, Cambridge recovered from a variety of archaeological investigations (photograph by Craig Cessford).

One exception to this are the eighteenth- to twentieth-century collegiate tablewares used at the University of Cambridge, England, which were manufactured and initially purchased for use in the dining halls of specific colleges, such as St John's (Figures 1-2). That locations of use are known with such certainty obviates the need inherent in most archaeological investigations to start with the depositional context as the prime biographical location associated with an object. This makes such ceramics particularly suitable for a fine-grained interpretation using a biographical approach, particularly when extended to assemblages of material rather than individual items (e.g. Blanco-González 2014; Cessford 2014a; Joy 2016).

The locales from which collegiate ceramics have been recovered can be broadly categorised into five types in terms of their functional, spatial and temporal domains, linked to an ideal or expected life course: 'Anticipated', 'Contingent', 'Proximate', 'Unknown' and 'Delayed' (Table 1). A significant proportion of Cambridge collegiate ceramics recovered archaeologically come from sites that can be classified as contingent, that is, locales with 


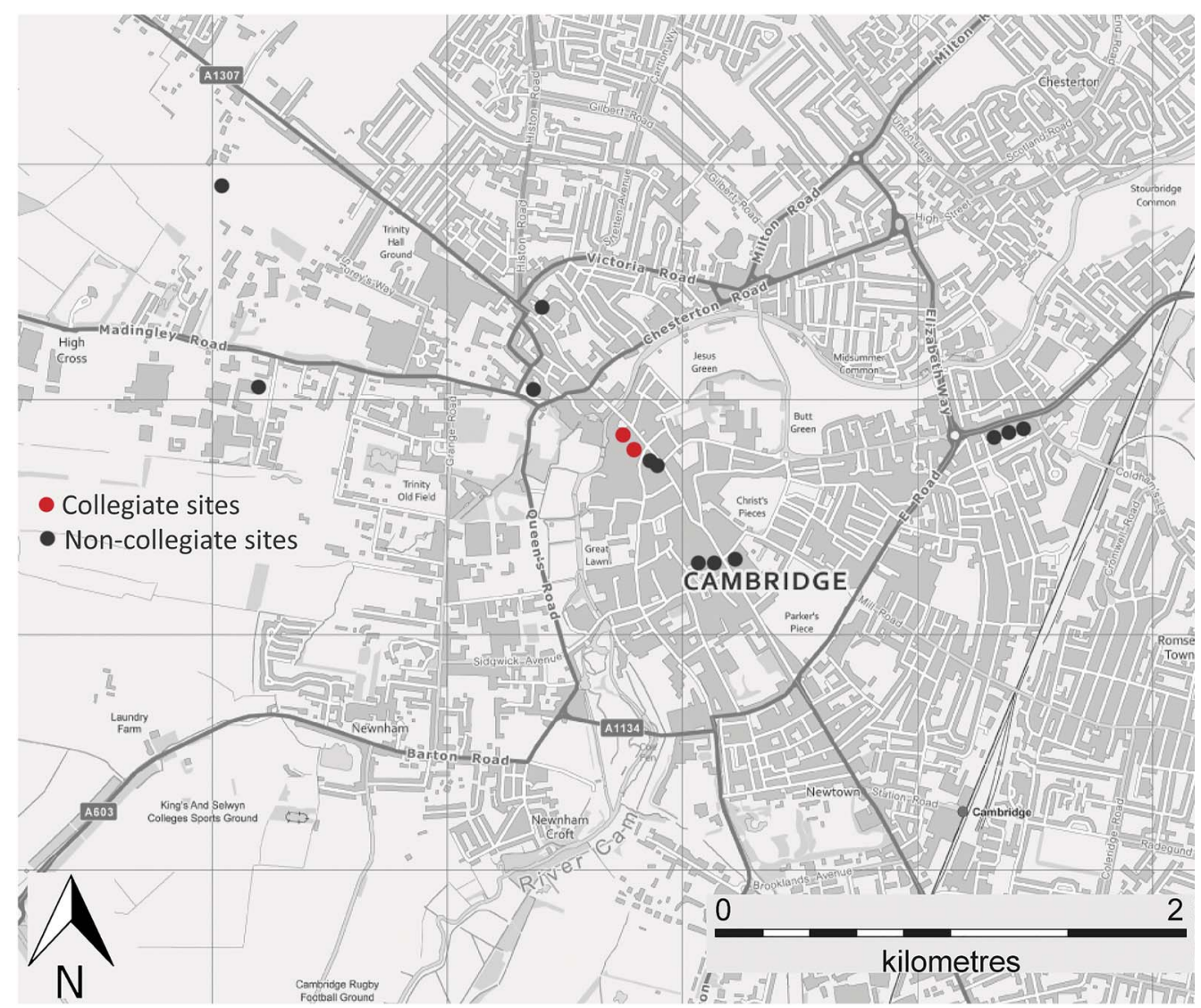

Figure 2. Map of Cambridge showing locations where late eighteenth-to early twentieth-century ceramics produced for use at St John's College were recovered during archaeological investigations (drawing by Craig Cessford, contains Ordnance Survey data (C) Crown copyright and database right 2018).

Table 1. Definitions of site categories.

Site category Definition

Anticipated Sites where the presence of collegiate ceramics might reasonably be expected, both spatially and temporally.

Proximate Sites with a direct collegiate connection, but not a location where collegiate ceramics would normally be expected to occur.

Contingent Sites that demonstrably possess no direct collegiate connection.

Unknown Sites where sufficient information does not survive to allow categorisation.

Delayed Sites where material occurs in contexts later than might reasonably be expected (can apply to anticipated, proximate, contingent or unknown sites). 
no direct collegiate connection. As will be illustrated through two case studies, such sites serve to demonstrate how complex the relationship between the locales of 'life' and 'death' may be for objects in urban contexts. This challenges the common assumption that the quantity of material deposited in primary use contexts was substantially greater than that disposed of elsewhere (e.g. Peña 2007: 39). In turn, this raises significant questions about the interpretation of distribution patterns (e.g. Gerrard 2011) and the combination of structural, artefactual and environmental evidence to produce integrated narratives of urban centres (e.g. Hall \& Hunter-Mann 2002; Bowsher et al. 2007).

\section{The University of Cambridge}

The University of Cambridge, founded c. 1209, is a federation of autonomous colleges, where governing authority and functions are divided between the university's central administration and the constituent colleges, although for most of its history, power and wealth has rested firmly with the latter (Leedham-Green 1996). By the late eighteenth century, there were 16 colleges, varying markedly in size and wealth, rising to 23 by the end of the nineteenth century. Broadly speaking, the colleges may be conceived of as grand households, comprising a master, fellows (academics), scholars (students) and servants. Until 1860 fellows had to resign if they married, so collegiate households were almost exclusively homosocial and adult. They were also relatively inward-looking institutions, a quality expressed architecturally through their quasi-monastic layouts, arranged around courtsalthough a significant proportion of students and almost all servants lived outside the college. Physically, the colleges dominated the core of the historic town, centred upon a 'university quarter' between the main street and the river. Breakfast, lunch and supper were simple meals, eaten privately or in small groups in the rooms of students or fellows, and usually ordered from the college kitchen or buttery. Dinner was a communal affair eaten in the college hall. There was a strict hierarchy of fellows and different groups of students seated separately, and those of higher status received better quality food. For the majority of students, dining was not a refined affair; the hall at Trinity College was "ugly, smoky, and smelling so strong of bread and meat, that it would be impossible for me to eat a morsel in it" (Mayor 1911: 124-25), with dining a "primitive" and "savage piece of business" where one "gobbled his fill" (Smith \& Stray 2003: 57). In contrast, at the top of the hierarchy, the fellows and some students could enjoy "one of the very best dinners ever put on a table" (Everett 1865: 134-35).

\section{Collegiate ceramics}

From c. 1760-1770 onwards, many collegiate ceramic dining sets were marked during manufacture by moulding, scratching, hand-painting or transfer-printing coats of arms, heraldic achievements, badges, names, college views or the name of the cook who supplied the crockery (Cessford 2016a, in press). Knowing with absolute certainty where these ceramics were used, combined with substantial bodies of documentary and cartographic evidence about where they were deposited, offers the opportunity for richly contextualised analysis and the reconstruction of plausible explanations for how ceramics moved between

(C) Antiquity Publications Ltd, 2018 
contexts of use and deposition. This has significant implications for the study of urban archaeology because it permits fine-grained analysis, allowing direct connections to be made between manufacture, acquisition, use and deposition.

One crucial assumption often made about these collegiate ceramics is that they would have remained within their respective colleges for the entirety of their use-lives: moving between the hall, the private rooms of fellows and students, the kitchen, the scullery and storage rooms. While this assumption is largely true, collegiate ceramics might also occasionally and legitimately leave a college. From 1860, fellows were allowed to marry and live outside college, and from then until the Second World War, college cooks sometimes supplied evening meals to these fellows, collecting the crockery the next morning. Groups of college cooks were occasionally involved in preparing food for major civic and university events outside their colleges, which may also have involved supplying ceramics, although such instances were the exception rather than the rule.

Beyond Cambridge colleges, a wide range of eighteenth- to twentieth-century institutions and other groups made use of marked ceramics, such as those associated with the military (Demers 2009), eating houses (Gooch 2007), university fraternities (Wilkie 2010: 184-92) and hospitals (Jeffries \& Braybrooke 2015: 254). These ceramics are, however, generally found in relatively small quantities and at anticipated sites linked almost exclusively to their prime locale of usage. Marked ceramics linked to hotels (Myers 2016) and shipping lines (Laister 2006) have been found in greater quantities, but again largely at anticipated sites. In contrast, Cambridge collegiate ceramics have been found in abundance at a variety of sites, many of which can be classified as proximate, contingent or delayed - that is, locales beyond the colleges and often without any direct link to them (Table 1). This is partly because the university constituted a significant proportion (7.8-11.4 per cent) of Cambridge's population between the eighteenth and twentieth centuries, whereas most of the other institutions noted above from this period formed a much smaller proportion of the urban centres where they were located. Second, the majority of college servants-including the cooks, who often supplied and owned college ceramics—and many undergraduates, resided outside the colleges, leading to a great deal of daily movement by people and ceramics, in and out of the colleges.

Many discoveries of collegiate ceramics have been made at anticipated sites that formed part of the commodity chain linking manufacturers and primary consumers (the colleges). During the period in question, the colleges stored refuse in above-ground enclosed containers or structures. Individuals known as 'scavengers' were employed to remove this waste on a regular basis. This material then joined the official civic refuse system and was transported to a number of 'common dunghills' around the town, where it was dumped before being used to backfill quarry pits in the surrounding fields about the town. The common dunghills and fields outside Cambridge can therefore be classified as anticipated sites. Collegiate ceramics have also been found on proximate sites with close links to colleges, or sites where such connections may have existed but are poorly documented (categorised here as unknown sites).

There are, however, a number of well-documented contingent sites where collegiate ceramics have been found without any direct college connections. Two of these locales, where large assemblages have allowed for a nuanced reading of the linkages between the contexts of use and deposition as a form of assemblage biography, are discussed below.

(C) Antiquity Publications Ltd, 2018 


\section{Grand Arcade}

The 1.5ha Grand Arcade site, excavated in 2005-2006 by the Cambridge Archaeological Unit (CAU), investigated significant portions of 14 properties within a single street block. Even though none of these properties were parts of colleges or occupied by college members, sherds relating to 34 identifiably collegiate vessels were recovered from 15 assemblages. The presence of many of these vessels, however, is readily explicable. Some were recovered from the property of a firm of ceramic retailers that supplied the colleges, while others were found at a property occupied by a college cook. Both of these are therefore anticipated sites.

The largest assemblage, comprising 20 vessels linked to five colleges, was deposited $c$. 1843-1845 in a cellar at the Cock Inn public house. Although the Cock Inn had no direct collegiate associations, it is possible to construct a convincing explanation of how this assemblage formed; as such, it can be considered a delayed contingent site (Figures 3-4; Cessford 2014a).

The earliest ceramics from this cellar are four plates from the colleges of Trinity Hall and Gonville \& Caius (c. 1770-1785). These plates were presumably 'inherited' by Richard Hopkins, the cook at Trinity Hall and Gonville \& Caius (c. 1800-1810), whose own name occurs on 11 vessels. There were also single plates of Bates Francis Tunwell (Emmanuel College, 1794-1806) and William Scott (St John's College, c. 1779-1808). Scott was a
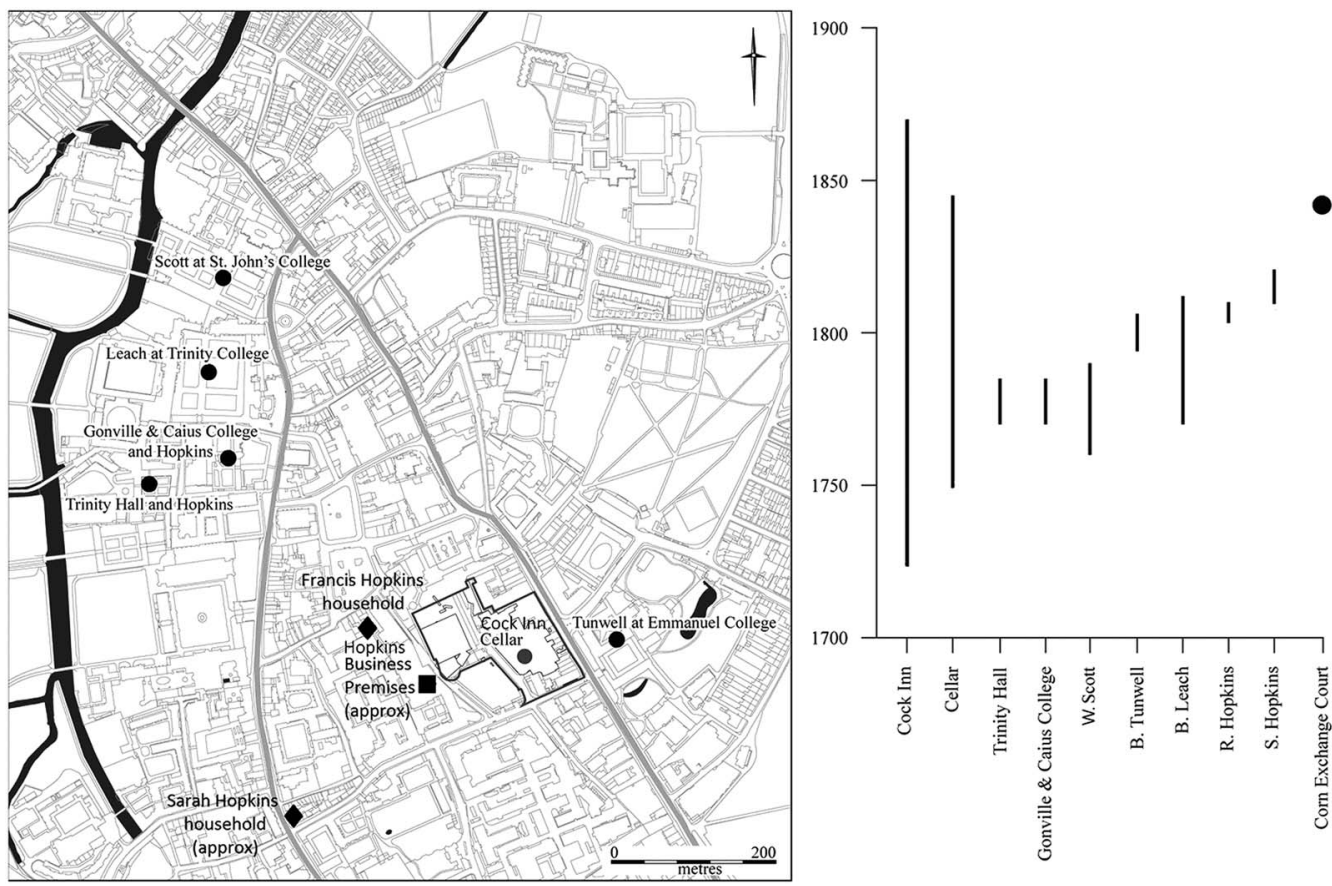

Figure 3. Map of colleges and cooks represented in the Cock Inn cellar assemblage (left) and date range of collegiate material in the Cock Inn cellar (right) illustrating the spatial and temporal elements of the assemblage biography (drawing by Vicki Herring). 

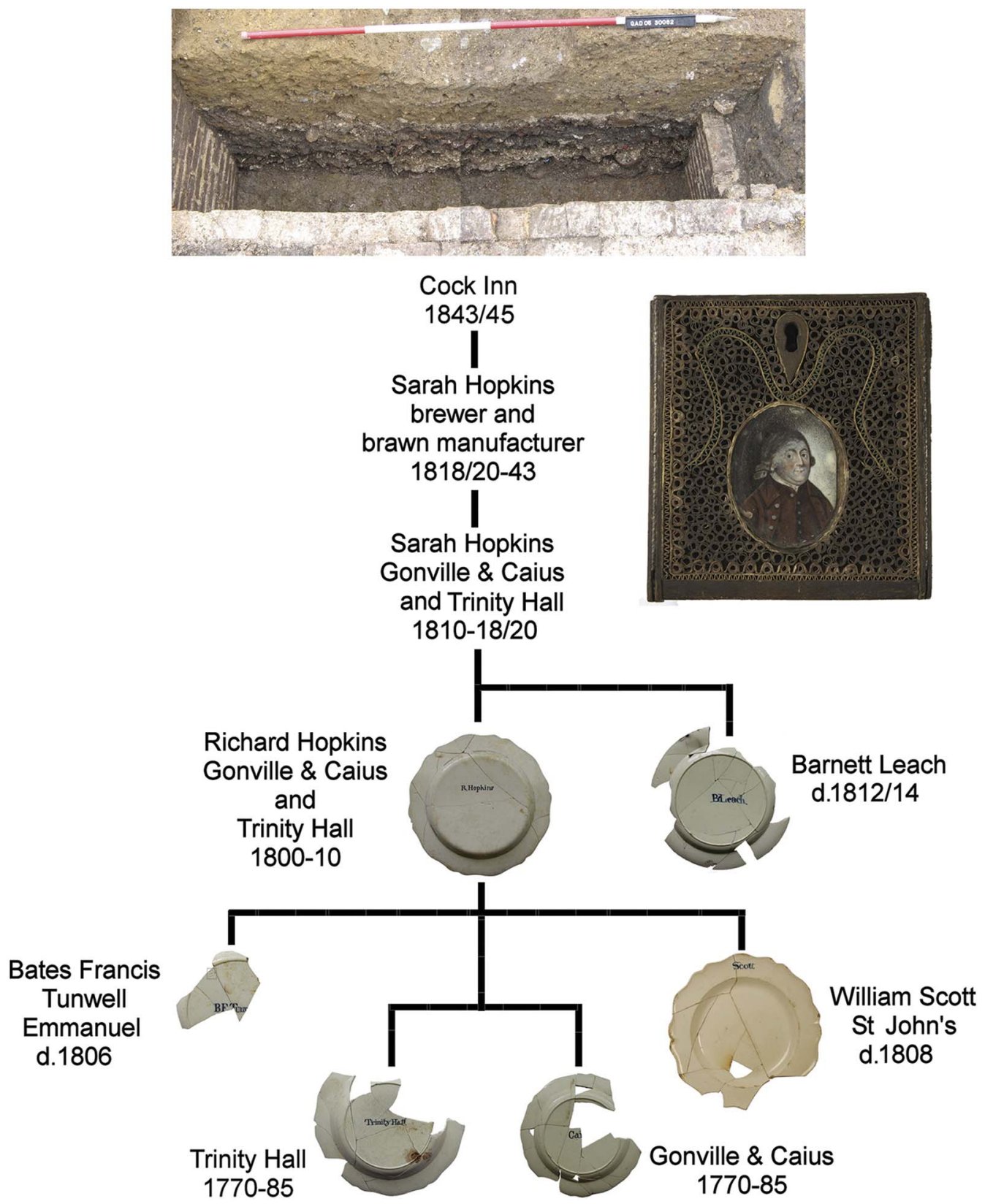

Figure 4. Diagram reconstructing the probable biography of the 'life' of the collegiate material in the assemblage recovered from the Cock Inn cellar. Section of the cellar excavation (top) and portrait of the cook Barnett Leach III on a box lid surrounded by quill work (right) (photographs by Craig Cessford, Dave Webb and Ric Leach; drawing by Craig Cessford).

witness at the marriage of Hopkins in 1787, so Richard probably acquired these vessels upon the retirement or death of the other cooks. These plates were then used by Richard's widow Sarah, who was the cook at the same colleges until 1818. Sarah appears not to have (C) Antiquity Publications Ltd, 2018 
commissioned any plates marked with her own name, but she probably acquired two vessels linked to the Leach family, cooks at Trinity College. The latter had been linked to the Hopkins family by marriage since 1787, and when the last cook retired or died in 18121814 , the vessels were presumably given to Sarah.

After ceasing to work as a cook, Sarah Hopkins, her son Richard and her brother Thomas Broadbent worked as brewers and brawn manufacturers on Slaughter House Lane. Sarah died in 1843, and in c. 1843-1845 part of the Cock Inn, located 100-150m from her premises on Slaughter House Lane (now Corn Exchange Street) was redeveloped. As brewers, Sarah and her son Richard may have had business connections with the Cock Inn. Alternatively, there may simply have been a serendipitous coincidence, with Richard disposing of his mother's possessions when the Cock Inn redevelopment required backfilling material.

Over 200 ceramic items were deposited in the cellar, so the 20 collegiate ceramics represent 9.8 per cent of the vessels from the assemblage. Other items, including what are probably personal effects, as well as vessels that probably derive from the Cock Inn, form very different elements of the assemblage biography. While the backfilled cellar represents a delayed contingent site for the collegiate ceramics, for other elements, it appears to be variously an anticipated, proximate or contingent site.

\section{Barnwell}

In the eighteenth century, Barnwell was a village, located $1.5 \mathrm{~km}$ from the centre of Cambridge and the colleges. After the enclosure of the surrounding town fields in 1807, it was developed rapidly with working-class housing, becoming a suburb of the town by the 1820s. Since 2012, the CAU and Oxford Archaeology East have conducted several excavations, covering 0.5 ha and investigating portions of around a dozen properties along the southern side of Newmarket Road. As at the Grand Arcade, none of these properties were parts of colleges, or occupied by students or fellows, but 189 collegiate vessels were recovered from 12 assemblages. None of these locations can be categorised as anticipated sites-they are, instead, a mixture of contingent and unknown sites.

Most of the vessels (170 in total) were used either to backfill a pit and other features, or to create a layer of hardcore during a substantial phase of property redevelopment $c$. 18771885, at what can be considered a contingent site (Figures 5-7; Cessford 2014b). The premises were occupied by the Fletcher family who ran an urban dairy on the outskirts of Cambridge. The redevelopment was probably linked to the 'Dairies, Cow-Sheds and MilkShops Order' of 1879, which established minimum building standards. The assemblage was only partially recovered, although at least 158 vessels from three separate Trinity Hall dining services-plus some food-storage and -preparation vessels-were identified. It was initially believed that this might relate to the wholesale replacement of some college dining services, but subsequent discoveries demonstrate that vessels for one of these services were still being manufactured as late as 1890 . This suggests that there may be a different explanation, for example, a shelf collapse, for the deposit of this large quantity of damaged crockery. 

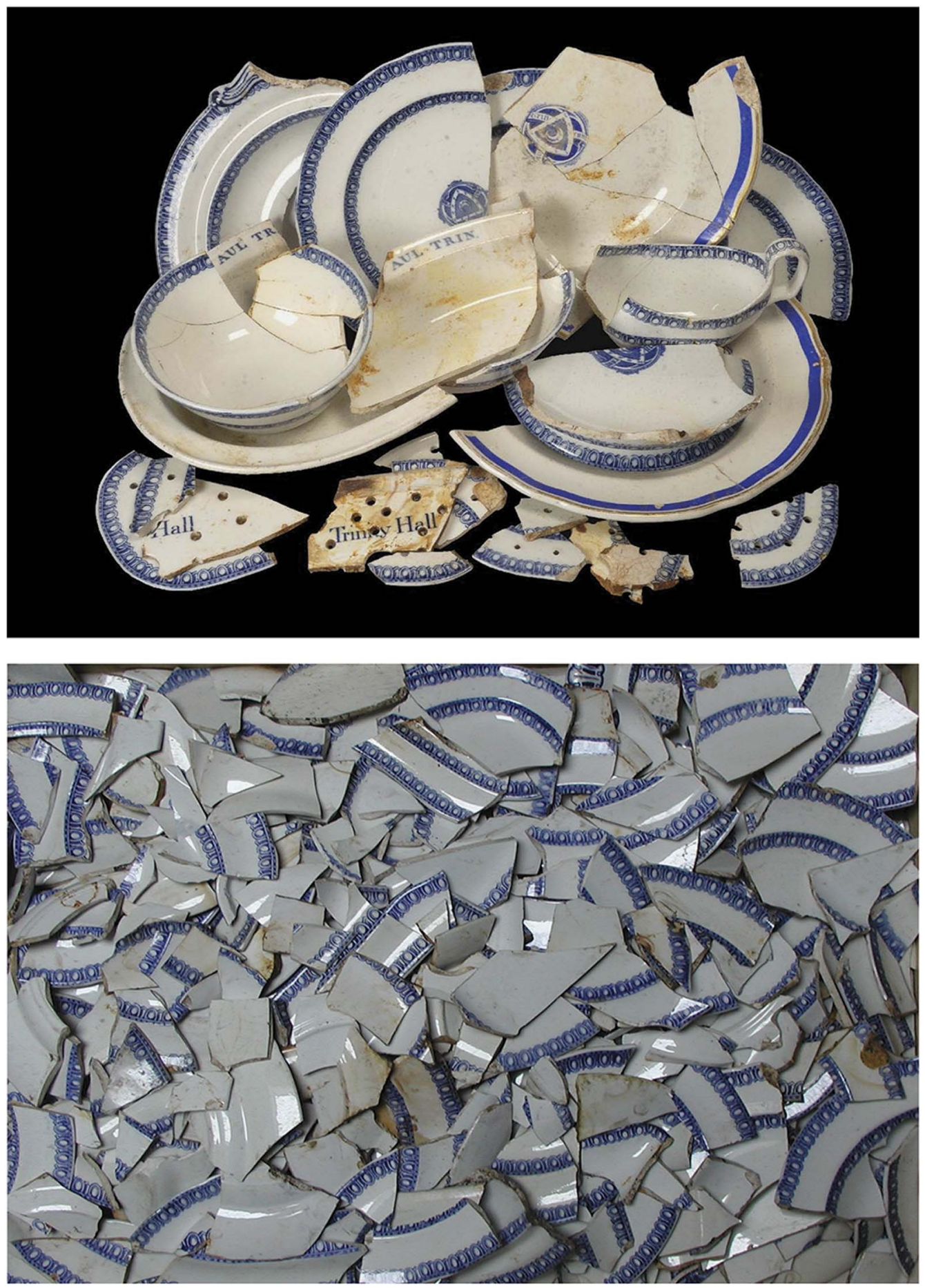

Figure 5. Part of a large assemblage of Trinity Hall ceramics associated with the redevelopment of the Fletcher family property c. 1877-1885 (photographs by Craig Cessford and Dave Webb).

(C) Antiquity Publications Ltd, 2018 


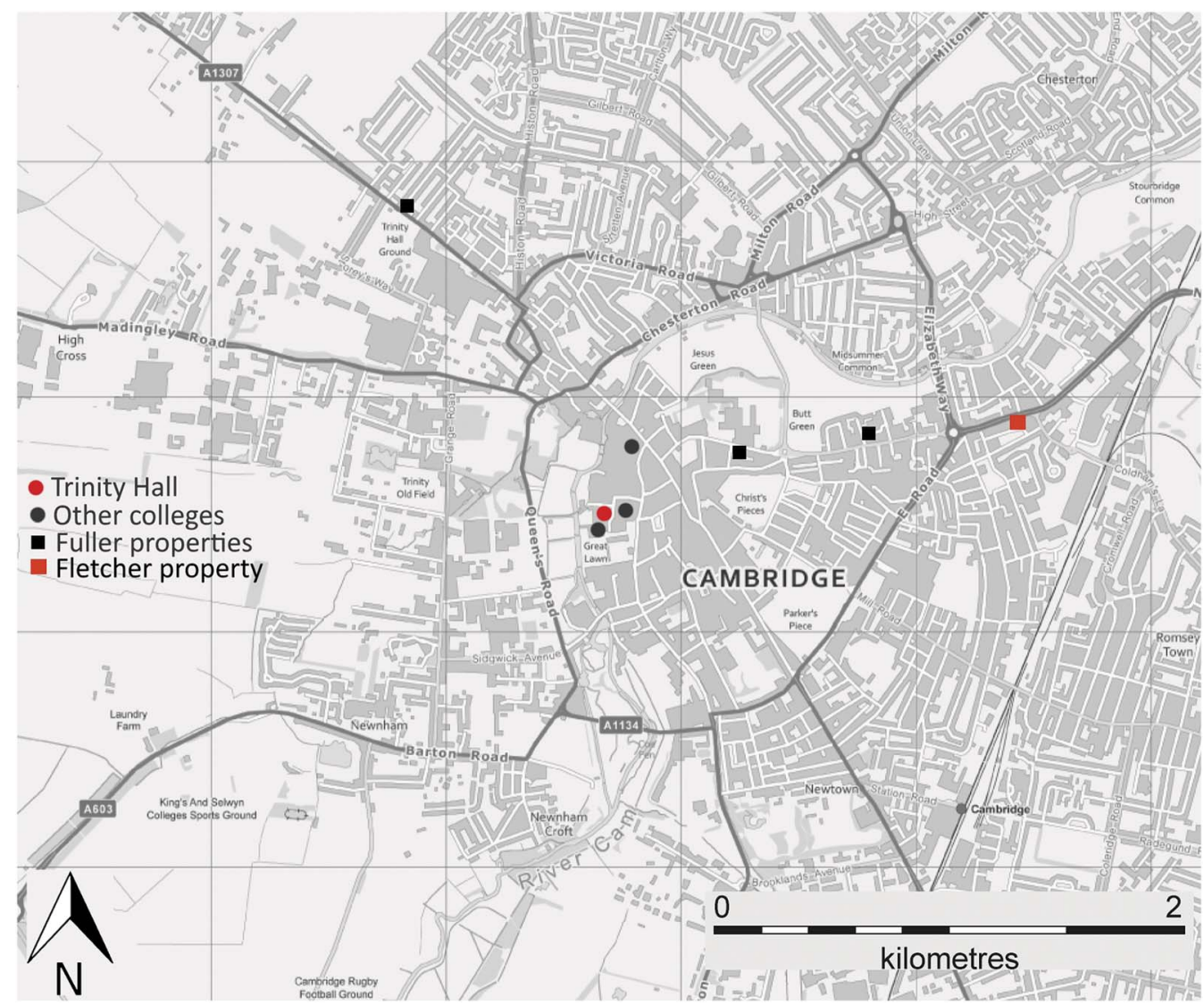

Figure 6. Map of Cambridge showing the location of colleges and the cooks' residences represented in the assemblage associated with the redevelopment of the Fletcher family property (drawing by Craig Cessford, contains Ordnance Survey data (C) Crown copyright and database right 2018).

Along with the Trinity Hall material, there are 12 other vessels that can be connected with other cooks and colleges. One is probably linked to Henry Brown, of Clare College (184047), while six are linked to one of his successors, William Moore (c. 1861-1873). There are also three vessels linked to John Fuller of Gonville \& Caius College (1839-1871) and later Clare College (1873-1874), one of which related specifically to Gonville \& Caius. When he died in 1874, John Fuller presumably had some Gonville \& Caius and Clare ceramics in his possession, including vessels 'inherited' from his predecessors, Brown and Moore, at Clare. On his death, John Fuller's ceramics may have come into the possession of his brother Alfred, the cook at Trinity Hall (1861-1884), who then took advantage of the disposal of a large group of Trinity Hall ceramics to get rid of this other unwanted material. Although there is no documented connection between Alfred Fuller and the Fletcher family (above), as a cook, Fuller would have been responsible for sourcing milk for the college and may have purchased from their dairy. Alternatively, the connection may have been more tenuous, for example, Alfred Fuller may have employed a haulier with a cart, already involved in the redevelopment of the Fletcher's premises, to dispose of the ceramics. 


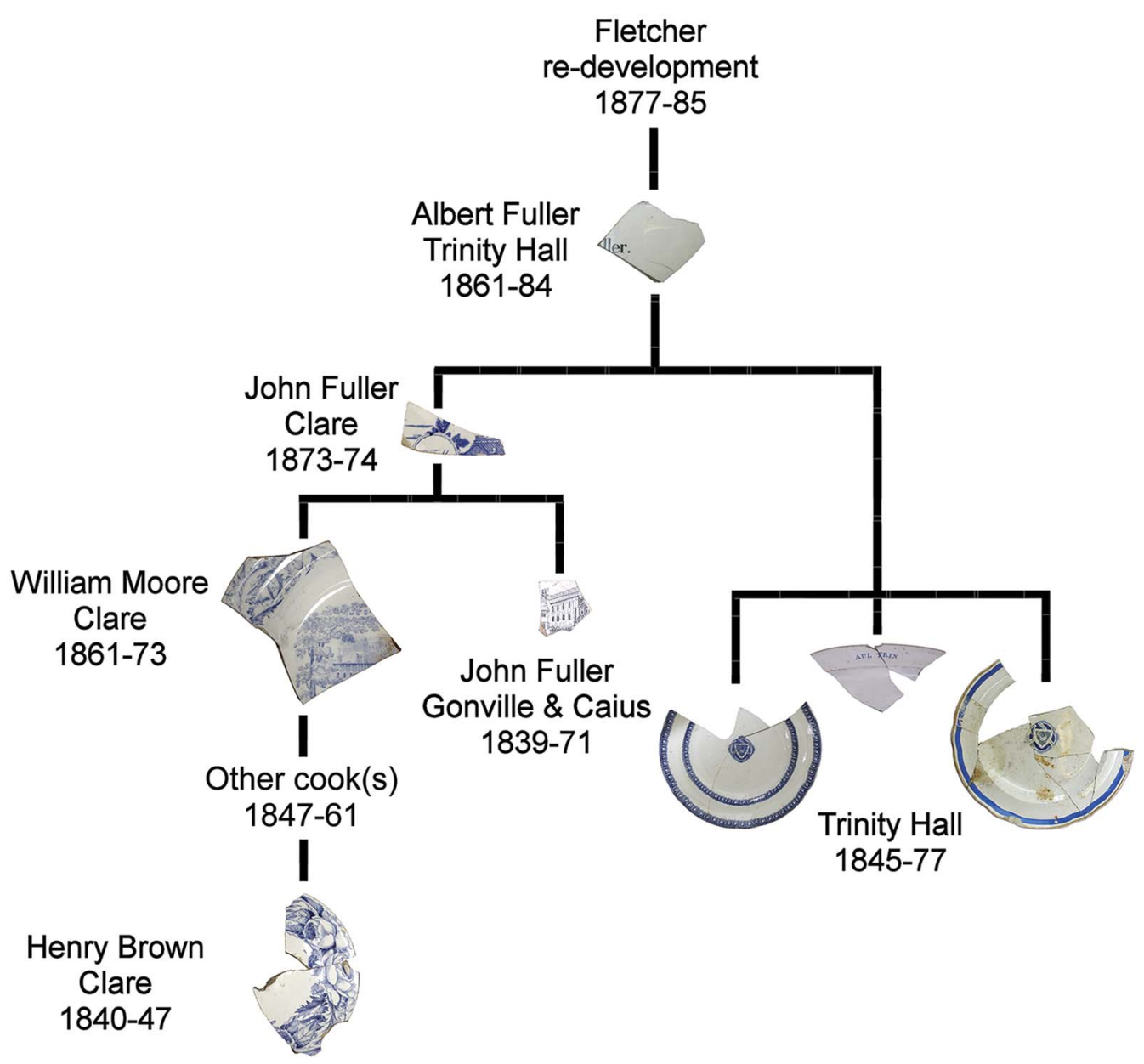

Figure 7. Diagram reconstructing the probable biography of the 'life' of the collegiate material in the assemblage associated with the redevelopment of the Fletcher family property (photographs by Craig Cessford).

Physically distant but proximate sites

Discoveries of nineteenth-century collegiate material from outside Cambridge clearly demonstrate that physical distance and degree of connection need not be directly related. Fragments of four mid nineteenth-century Queens' College plates from two different services were recovered at Brook Farm in Haslingfield, a village $7 \mathrm{~km}$ south-west of Cambridge (Figure 8). This is the farthest from Cambridge that collegiate ceramics have been recovered archaeologically, too far for refuse disposal to be considered a reasonable explanation. Queens' College acquired substantial landholdings in Haslingfield in the late fifteenth century, which it leased to tenants until the mid twentieth century. It is probable that the presence of the plates relates to this link, probably as some form of gift, meaning that this site is perhaps best thought of as a proximate locale.

Meanwhile, sherds from two mid nineteenth-century Trinity College plates, from two different services, were found in a field near Coton, $5 \mathrm{~km}$ east of the college. This suggests that (C) Antiquity Publications Ltd, 2018 
the Haslingfield example is not unique, although in the case of the Coton plates, the link is less clear, as the colleges with closely documented connections to the village are King's,

Queens', St Catharine's and St John's, rather than Trinity; consequently, this locale should be categorised as an unknown site.

In the 1960s, approximately 230 complete late eighteenth- to mid nineteenth-century wine bottles with Emmanuel College seals were found $80 \mathrm{~km}$ north-west of Cambridge in a cellar at the Old Rectory in North Luffenham, Rutland (Figure 8). Emmanuel gained the advowson - the right to nominate individuals to a vacant church position-of this parish in 1591. This right was still being exercised in the mid nineteenth century, when the college ceased using sealed bottles. It seems unlikely that empty bottles would have been transported this far, suggesting that they may have contained wine.

The date of the bottles suggests that the fellow John Weller (1794-1862) was probably responsible for their relocation. Weller was described as "a most eccentric man [...] of great obstinacy of character" who fell out with the other examiners of the Classical Tripos in 1827, left Emmanuel "under a bad omen" for North Luffenham in 1837 and found it "truly a hard and thankless office" (Anonymous 1908: 7-8). This prompts the question of whether the bottles and their putative contents were given to Weller by the college or if he illicitly appropriated them. Whatever the case, this represents a proximate site. In a similar instance, the advowson for Hempstead, Norfolk, $120 \mathrm{~km}$ north-east of Cambridge, was held by King's College; a cesspit at the rectory, backfilled in the 1890s, contained a tile decorated with the college crest (Licence 2015: 78) (Figure 8).

\section{Classifying deposition}

Although specific depositional circumstances are often highly idiosyncratic, it is nonetheless possible to categorise depositional sites according to distinct characteristics related to assemblages of marked collegiate vessels (Table 2). In general, sherd size, weight and damage do not vary significantly between the different categories of sites, meaning that the relative prevalence of collegiate ceramics within overall eighteenth- to twentieth-century ceramic assemblages becomes a useful metric. A relatively crude but effective measure of this is to divide the number of marked collegiate vessels by the weight of the total eighteenth- to twentieth-century ceramic assemblage (Table $3 \&$ Figure 9). The highest values relate

(C) Antiquity Publications Ltd, 2018 
Table 2. Attributes of college-related material from different types of sites; the attributes are based upon excavated assemblages from Cambridge and Oxford where collegiate ceramics have been recovered.

\begin{tabular}{|c|c|c|c|c|c|c|}
\hline Site type & $\begin{array}{l}\text { Site } \\
\text { category }\end{array}$ & $\begin{array}{l}\text { Single/ } \\
\text { multiple } \\
\text { colleges }\end{array}$ & $\begin{array}{l}\text { Semi- } \\
\text { complete } \\
\text { vessels }\end{array}$ & $\begin{array}{l}\text { Dominated } \\
\text { by unusual } \\
\text { vessel forms }\end{array}$ & $\begin{array}{l}\text { Homogeneous } \\
\text { dating }\end{array}$ & $\begin{array}{l}\text { Numerous } \\
\text { vessels }\end{array}$ \\
\hline Retail establishments & Anticipated & Multiple & Yes & No & Yes & Yes \\
\hline College & Anticipated & Single & No & No & No & Yes \\
\hline Civic discard & Anticipated & Multiple & Yes & No & Yes & Yes \\
\hline $\begin{array}{l}\text { Non-collegiate } \\
\text { university sites }\end{array}$ & Proximate & Multiple & Yes & No & No & Yes \\
\hline $\begin{array}{l}\text { Premises of college } \\
\text { servants }\end{array}$ & Proximate & $\begin{array}{l}\text { Typically } \\
\text { single }\end{array}$ & No & No & Yes & Yes \\
\hline $\begin{array}{l}\text { Domestic and } \\
\text { business sites with a } \\
\text { close connection to } \\
\text { a college }\end{array}$ & Proximate & Single & No & No & Yes & Yes \\
\hline Charitable gifts & Proximate & Single & Yes & No & No & Yes \\
\hline $\begin{array}{l}\text { Undergraduate } \\
\text { lodgings }\end{array}$ & Proximate & Single & Yes & & Yes & No \\
\hline Hospital & Proximate & Multiple & Yes & Yes & Either & Yes \\
\hline $\begin{array}{l}\text { Domestic and } \\
\text { business sites } \\
\text { without a close } \\
\text { connection to a } \\
\text { college }\end{array}$ & Contingent & Either & Yes & No & Either & Either \\
\hline Various & Contingent & Multiple & Yes & No & Either & Either \\
\hline
\end{tabular}

to colleges (anticipated sites), followed by locales closely linked to colleges (proximate sites), while the lowest are areas of town with no particular collegiate associations (contingent sites). Sites of civic refuse disposal, with material from both colleges and the rest of the town, can be classified as anticipated sites and have intermediate values. Physical proximity to the colleges does not appear to affect the values; Barnwell, which has no particular collegiate associations and is located several kilometres away, has higher values than the much closer Grand Arcade. One site known as Christ's Lane, located close to the Grand Arcade, provided accommodation for college servants. It constitutes a proximate site and had a higher value, despite being indistinguishable in terms of other architectural and material culture remains.

\section{Other instances of contingent deposition}

The deposition of material at contingent locales is not limited to ceramics associated with Cambridge colleges, but also recognised in other periods and places. It is unsurprising that there are assemblages associated with the University of Oxford involving similar processes to (C) Antiquity Publications Ltd, 2018 
Table 3. Prevalence of collegiate ceramics by weight of overall assemblage. '*' indicates values for sites with particular assemblages with large numbers of collegiate vessels excluded.

\begin{tabular}{|c|c|c|c|c|}
\hline Site & Site type and category & $\begin{array}{l}\text { No. of marked } \\
\text { collegiate vessels }\end{array}$ & $\begin{array}{l}\text { Assemblage } \\
\text { weight (kg) }\end{array}$ & $\begin{array}{l}\text { Prevalence } \\
\text { (no./kg) }\end{array}$ \\
\hline $\begin{array}{l}\text { St John's College } \\
\text { First Court }\end{array}$ & College (anticipated) & 7 & 1.21 & 5.79 \\
\hline $\begin{array}{l}\text { Penitentiary of St } \\
\text { John's College }\end{array}$ & $\begin{array}{l}\text { Occupied by college facilities and } \\
\text { servants (proximate) }\end{array}$ & 6 & 15.72 & 0.38 \\
\hline Christ's Lane & $\begin{array}{l}\text { Occupied by college servants } \\
\text { (proximate) }\end{array}$ & 3 & 8.39 & 0.36 \\
\hline West Fields & Civic discard (anticipated) & 21 & 87.27 & 0.24 \\
\hline $\begin{array}{l}\text { St Clement's } \\
\text { Gardens }\end{array}$ & $\begin{array}{l}\text { Owned by college and sublet } \\
\text { (proximate) }\end{array}$ & 5 & 20.91 & 0.24 \\
\hline $\begin{array}{l}\text { Civil war castle } \\
\text { ditch }\end{array}$ & Civic discard (anticipated) & 3 & 16.00 & 0.19 \\
\hline $\begin{array}{l}\text { St John's } \\
\text { Triangle }\end{array}$ & $\begin{array}{l}\text { Domestic and business premises } \\
\text { (mixed: proximate and } \\
\text { contingent) }\end{array}$ & 14 & 113.54 & 0.12 \\
\hline Vicar's Farm & Farm (contingent) & 3 & 34.93 & 0.09 \\
\hline Grand Arcade & $\begin{array}{l}\text { Domestic and business premises } \\
\text { (mixed: proximate and } \\
\text { contingent) }\end{array}$ & $34(14)^{*}$ & 496.80 & $0.07(0.03)^{*}$ \\
\hline Barnwell & $\begin{array}{l}\text { Domestic and business premises } \\
\text { (contingent) }\end{array}$ & $189(19)^{*}$ & 441.36 & $0.43(0.04)^{*}$ \\
\hline Total & & 135 & 1236.13 & 0.10 \\
\hline
\end{tabular}

those identified for Cambridge colleges (Cessford 2016b). A non-collegiate example from Cambridge is that of an assemblage dating to $c$. 1775-1780 linked to a coffeehouse run by William Clapham $c .1750-1779$, which has nine vessels marked with the proprietor's initials, but also four vessels with other initials or names (Cessford et al. 2017). Two are from the Sun's Coffee Room and the Rose Inn, and appear to be linked to coffee-house patrons 'ordering out' for meals or drinks from other establishments. The markings were presumably to facilitate the return of the vessels, and such ordering out at least partially explains the regularity with which material is recovered at other establishments and domestic premises (e.g. Hassall et al. 1985: 216; Owens et al. 2010: 219; Owens \& Jeffries 2016: 821-23).

John Murray, $4^{\text {th }}$ Earl of Dunmore (1730-1809) and last crown governor of Virginia (1771-1775), took with him to Williamsburg in 1771 a set of Chinese porcelain armorial ceramics manufactured c. 1750-1760. In 1775, early in the American Revolutionary War, Dunmore was forced to evacuate the Governor's Palace in Williamsburg, abandoning his possessions. Some of his armorial porcelain has been recovered at the palace, but examples have also been found at six other Williamsburg sites (Noël Hume 1969: 42). These vessels may either have been carried off when the palace was ransacked in 1775 , or sold at auction in 1776. In either scenario, some of Williamsburg's inhabitants dined off the armorial porcelain of their vanquished adversaries at contingent sites. In another case, an early twentieth-century 


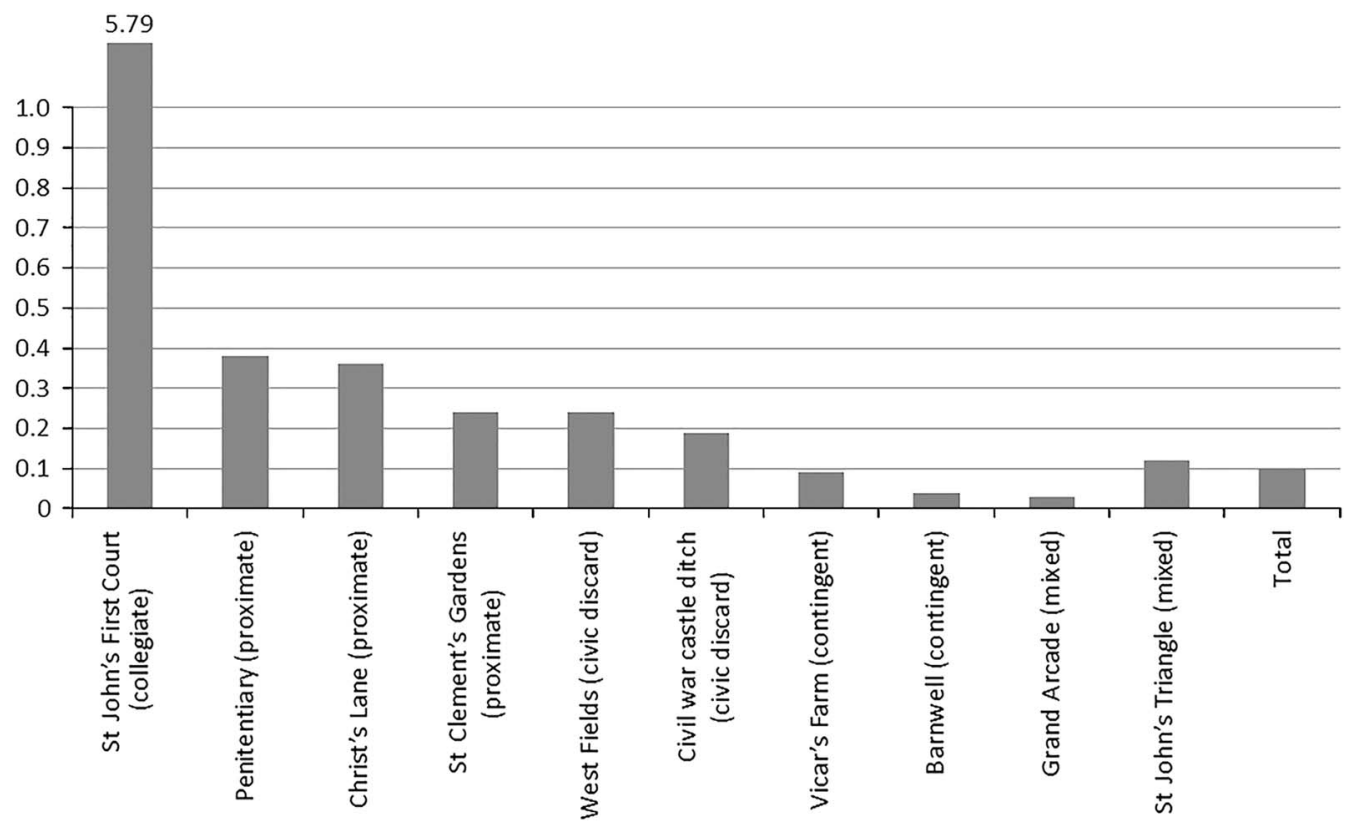

Figure 9. Prevalence of marked collegiate ceramic vessels according to number and weight per kilogram (Craig Cessford).

soup bowl from the Atlantic Lunch restaurant in Washington, D.C. was recovered from a contingent site in St Mary's City, Maryland, located $90 \mathrm{~km}$ away where a long-lived community connection between these two locations has been demonstrated (Miller 1984).

Comparisons with pre-modern parallels are often problematic, not least because the meaning of ceramic markings is debatable. Even when their significance can be determined, it can still be difficult to identify where vessels were actually used (e.g. Spence 2015). One possible parallel is fifth-century BC Athens where some vessels were marked with the names of individuals or as public property (Lang 1976: 51-52; Rotroff \& Oakley 1992). Those marked as public property include significant numbers from distinctive large assemblages in the agora linked predominantly to the consumption of alcohol. These were probably used in nearby public dining facilities serving the city magistrates, and may be categorised as either anticipated or proximate sites. Three such vessels have also been found nearly $80 \mathrm{~km}$ away in Corinth; this should probably be categorised as a contingent site with one possible explanation being that the vessels accompanied Athenian envoys (Donati 2010: 7-8).

All of these examples of marked ceramics clearly demonstrate that deposition at contingent sites, often distant from the sites of primary usage, is neither exceptional nor confined to collegiate ceramics, but rather a much more widespread phenomenon.

\section{Discussion}

The distribution of archaeologically recovered ceramics that can be definitively associated with Cambridge colleges indicates that while some come from locales where their presence might reasonably be anticipated, a significant proportion appear at unexpected sites. Many (C) Antiquity Publications Ltd, 2018 
are found on proximate sites with a direct connection to the colleges, but in some instances, there is greater spatial and temporal distance between the locales of usage and deposition and the connections are less direct and more contingent. Similarly complex artefact biographies can be recognised in relation to the use and deposition of marked ceramics in other eighteenth- to twentieth-century and earlier historical contexts, indicating that this situation is far from unique and raises wider questions for urban archaeologists.

The classification of those locales where collegiate ceramics have been found as anticipated, proximate, contingent, unknown and delayed sites, along with the recognition that these objects have complex biographies, permits a nuanced consideration of the linkages between the contexts of use and deposition, and the relationships between various human actors and objects. In many respects, it is the more counter-intuitive discoveries that are the most informative. Anticipated sites can provide some insights, but effectively just confirm that colleges used collegiate ceramics. Proximate sites are more informative, archaeologically documenting and illuminating connections that were in some instances already known. Contingent sites that possess no direct collegiate connections, but instead probably relate to a series of serendipitous coincidences, are the most challenging to understand. It is here that the relationship between the objects and human actors-particularly those that might traditionally be accorded relatively little significance in considerations of collegiate ceramics such as collegecooks and hauliers-come most clearly into focus. While locales categorised as unknown sites are less informative, it is worth reflecting that the findspots of most archaeological material culture fall into this class, with no sense of whether they are anticipated, proximate or contingent. It is apparent that during their lifespans some collegiate ceramics were moved from anticipated to proximate contexts, before the material was deposited at delayed contingent sites.

Cambridge collegiate ceramics provide a useful case study, and suggest that current archaeological approaches to urban sites inadequately address the relationship between locales of use and deposition. Social connections between individuals and groups, be they proximate or contingent, are more significant than spatial proximity. This suggests that a fundamental reconceptualisation of urban archaeological sites is required, one that deals with the locales that people and objects move through on various timescales and then leave, via conduits of divestment (Gregson et al. 2007) or dispersal (Lucas 2014). Rough and necessarily approximate calculations suggest that it is unlikely that more than five per cent of collegiate ceramics were deposited on college sites. Most collegiate ceramics, therefore, moved in decidedly mysterious ways between contexts of use and deposition. Without the benefit of marking, the overall distribution patterns of depositional contexts from which ceramics associated with particular colleges have been recovered would be insufficient to allow those colleges to be pinpointed specifically (Figure 2). Instead, the ceramics are evidence of numerous extended assemblage biographies, spanning both the commodity chains linking manufacturers and primary consumers and the multiple contingent conduits of divestment or dispersal.

\section{Acknowledgements}

I am indebted to many colleagues at the Cambridge Archaeological Unit, particularly Richard Newman, as well as to Rob Atkins, Michael Coles, Kasia Gdaniec and Nigel Jeffries for providing information on various discoveries. Marcus Brittain and Charles Orser provided helpful comments on a draft of the text, and it has been improved by the comments of two anonymous reviewers. This paper was written during my time as the field archaeologist in

(C) Antiquity Publications Ltd, 2018 
residence at the McDonald Institute for Archaeological Research, and has benefited from stimulating discussions with members of the Department of Archaeology, University of Cambridge.

\section{References}

Anonymous. 1908. North Luffenham. Rutland Magazine and County Historical Record 3(17): $1-8$.

Blanco-GonzÁlez, A. 2014. Tracking the social lives of things: biographical insights into Bronze Age pottery in Spain. Antiquity 88: 441-55. https://doi.org/10.1017/S0003598X00101103

Bowsher, D., T. Dyson, N. Holder \& I. Howell. 2007. The London Guildhall. An archaeological history of a neighbourhood from early medieval to modern times (MoLAS Monograph 36). London: Museum of London Archaeology Service.

Cessfford, C. 2014a. Assemblage biography and the life course: an archaeologically materialised temporality of Richard and Sarah Hopkins. International Journal of Historical Archaeology 18: 555-90.

https://doi.org/10.1007/s10761-014-0270-5

- 2014b. An assemblage of collegiate ceramics: mid-nineteenth century dining at Trinity Hall, Cambridge. Archaeological Journal 171: 340-80. https://doi.org/10.1080/00665983.2014.11078270

- 2016a. Cambridge College Ceramics $c$. 1760-1900: a brief overview. Proceedings of the Cambridge Antiquarian Society 105: 109-25.

- 2016b. John Webb Cluff: a postscript. PostMedieval Archaeology 50: 426-27. https://doi.org/10.1080/00794236.2016.1232978

- In press. Cambridge colleges and their crockery, from the mid- $18^{\text {th }}$ century to the present day. English Ceramic Circle Transactions 28.

Cessfford, C., A. Hall, V. Herring \& R. Newman. 2017. To Clapham's I go: material from a mid-late $18^{\text {th }}$ century Cambridge coffee house. Post-Medieval Archaeology 51: 372-426. https://doi.org/10.1080/00794236.2017.1363146

Demers, P.A. 2009. 'Crestspeak': British military crested ceramics, military socialization, and collective memory. International Journal of Historical Archaeology 13: 366-84. https://doi.org/10.1007/s10761-009-0085-y
Donati, C.J. 2010. Marks of state ownership and the Greek agora at Corinth. American Journal of Archaeology 114: 3-26. https://doi.org/10.3764/aja.114.1.3

Everetr, W. 1865. On the Cam. Lectures on the University of Cambridge in England. Cambridge: Sever \& Francis.

Gerrard, J. 2011. New light on the end of Roman London. Archaeological Journal 168: 181-94. https://doi.org/10.1080/00665983.2011.11020833

Gooch, T. 2007. Hinton's: a $19^{\text {th }}$ century, eating house in Southwark. London Archaeologist 10: 268-71.

Gregson, N., A. Metclafe \& L. Crewe. 2007. Moving things along: the conduits and practices of divestment in consumption. Transactions of the Institute of British Geographers 32: 187-200. https://doi.org/10.1111/j.1475-5661.2007.00253.x

HaHN, H.P. \& H. Weiss (ed.). 2013. Mobility, meaning \& transformations of things. Oxford: Oxbow.

Hall, R.A. \& K. Hunter-Mann. 2002. Medieval urbanism in Coppergate: refining a townscape. York: Archaeology of York.

Hassall, T.G., C.E. Halpin \& M. Mellor. 1985. Excavations in St Ebbe's, Oxford, 1967-1976: part II, post-medieval domestic tenements and the post-dissolution site of the Greyfriars. Oxoniensia 49: 153-275.

Jefrries, N. \& T. Braybrooke. 2015. Development of the former Radcliffe Infirmary, Oxford, 1770-1900. Post-Medieval Archaeology 49: 238-68. https://doi.org/10.1080/00794236.2015.1124195

Joy, J. 2015. 'Things in process': biographies of British Iron Age pits, in D. Boschung, P.-A. Kreuz \& T. Kienlin (ed.) Biography of objects. Aspekte eines kulturhistorischen Konzepts (Morphomata 31): 125-41.

- 2016. Hoards as collections: re-examining the Snettisham Iron Age hoards from the perspective of collecting practice. World Archaeology 48: 239-53. https://doi.org/10.1080/00438243.2016.1152197 Joyce, R.A. \& S.D. GiLlespie (ed.). 2015. Things in motion. Object itineraries in anthropological practice. Santa Fe (NM): SAR.

(C) Antiquity Publications Ltd, 2018 
Kopytoff, I. 1986. The cultural biography of things: commoditization as process, in A. Appadurai (ed.) The social life of things, commodities in cultural perspective: 64-91. Cambridge: Cambridge University Press. https://doi.org/10.1017/CBO9780511819582.004

LANG, M.L. 1976. The Athenian agora XXI: graffiti and dipinti. Princeton (NJ): American School of Classical Studies at Athens.

Laister, P. 2006. Mariners memorabilia. A guide to British shipping company china of the $19^{\text {th }}$ and $20^{\text {th }}$ centuries (privately published).

Leedham-Green, E. 1996. A concise history of the University of Cambridge. Cambridge: Cambridge University Press.

LiCENCE, T. 2015. What the Victorians threw away. Oxford: Oxbow.

LuCAs, G. 2014. Conduits of dispersal.

Dematerializing an early twentieth-century village in Iceland, in B. Olsen \& P. Pétursdóttir (ed.) Ruin memories materiality, aesthetics and the archaeology of the recent past: 305-18. Abingdon: Routledge.

Mayor, J.E.B. 1911. Cambridge under Queen Anne: illustrated by memoir of Ambrose Bonwicke and diaries of Francis Burman and Zacharias Conrad von Uffenbach. London: Deighton, Bell \& Co. \& Bowes \& Bowes.

Miller, G.L. 1984. Ode to a lunch bowl: the Atlantic Lunch as an interface between St Mary's County, Maryland, and Washington, D.C. Northeast Historical Archaeology 13: 2-8. https://doi.org/10.22191/neha/vol13/iss1/2

Myers, A. 2016. The significance of hotel-ware ceramics in the twentieth century. Historical Archaeology 50: 110-26.
https://doi.org/10.1007/BF03377328

Nö̈l Hume, I. 1969. Pottery and porcelain in Colonial Williamsburg's archaeological collections

(Colonial Williamsburg Archaeological Series 2). Williamsburg: The Colonial Williamsburg Foundation.

Owens, A. \& N. Jefrries. 2016. People and things on the move: domestic material culture, poverty and mobility in Victorian London. International Journal of Historical Archaeology 20: 804-27.

https://doi.org/10.1007/s10761-016-0350-9

Owens, A., N. Jefrries, K. Wehner \& R.

FEATHERby. 2010. Fragments of the modern city: material culture and the rhythms of everyday life in Victorian London. Journal of Victorian Culture 15: 212-25.

https://doi.org/10.1080/13555502.2010.491657

PeÑA, J.T. 2007. Roman pottery in the archaeological record. Cambridge: Cambridge University Press. https://doi.org/10.1017/CBO9780511499685

RotrofF, S.I. \& J.H. OAKLEY. 1992. Debris from a public dining place in the Athenian agora. Hesperia Supplement 25: i-xiii, 1-154, figs 1-26, pls 1-64. https://doi.org/10.2307/1353998

Smith, J. \& C. Stray. 2003. Cambridge in the 1830s. The letters of Alexander Chisholm Gooden 1831-1841. Woodbridge: Boydell.

Spence, M.W. 2015. Personal art in Teotihuacan: the thin orange graffiti. Ancient Mesoamerica 26: 295-311. https://doi.org/10.1017/S0956536115000218

WILKIE, L.A. 2010. The lost boys of Zeta Psi: a historical archaeology of masculinity in a university fraternity. Berkeley: University of California Press.

Received: 15 March 2017; Revised: 9 November 2017; Accepted: 10 February 2018 